\title{
Effect of sward height and concentrate supplementation on forage dry matter intake, digestibility and grazing time of spring- calving beef cows
}

Ondieki J. Gekara

West Virginia University

Follow this and additional works at: https://researchrepository.wvu.edu/etd

\section{Recommended Citation}

Gekara, Ondieki J., "Effect of sward height and concentrate supplementation on forage dry matter intake, digestibility and grazing time of spring-calving beef cows" (1999). Graduate Theses, Dissertations, and Problem Reports. 976.

https://researchrepository.wvu.edu/etd/976

This Thesis is protected by copyright and/or related rights. It has been brought to you by the The Research Repository @ WVU with permission from the rights-holder(s). You are free to use this Thesis in any way that is permitted by the copyright and related rights legislation that applies to your use. For other uses you must obtain permission from the rights-holder(s) directly, unless additional rights are indicated by a Creative Commons license in the record and/ or on the work itself. This Thesis has been accepted for inclusion in WVU Graduate Theses, Dissertations, and Problem Reports collection by an authorized administrator of The Research Repository @ WVU. For more information, please contact researchrepository@mail.wvu.edu. 


\title{
Effect of Sward Height and Concentrate Supplementation on Forage Dry Matter Intake, Digestibility and Grazing Time of Spring- calving Beef Cows
}

\author{
Ondieki J. Gekara, BS. Agr. \\ Thesis submitted to the \\ College of Agriculture, Forestry and Consumer Sciences \\ West Virginia University \\ In partial fulfillment of the requirements \\ for the degree of \\ Master of Science
in
Animal and Veterinary Sciences
}

Edward C. Prigge, Chair

William H. Hoover

${ }^{1}$ William B. Bryan

Division of Animal and Veterinary Sciences

${ }^{1}$ Division of Plant and Soil Sciences

Morgantown, West Virginia

1999

Keywords: Pasture, Sward Height, Cattle, Intake, Digestibility, Grazing Time Supplementation

Copyright 1999 Ondieki J. Gekara 


\title{
ABSTRACT \\ Effect of Sward Height and Concentrate Supplementation on Forage Dry Matter Intake, Digestibility and Grazing Time of Spring-calving Beef Cows
}

\begin{abstract}
Ondieki J. Gekara
To establish the effect of sward height $(\mathrm{SH})$ and concentrate supplementation on performance of grazing cattle, twenty-four cross bred Angus beef cow-calves were randomly assigned to two SH treatments $(4-8$ or $8-11 \mathrm{~cm})$ with three supplement levels: $6.24,3.12$ or $0 \mathrm{~kg} / \mathrm{d}$. The study was conducted in three periods (P): May (P1), June/July (P2) and August (P3) in 1996. There was no SH $\mathrm{x}$ supplement level $\mathrm{x}$ period or $\mathrm{SH} x$ supplement level interaction $(\mathrm{P}>.10)$ on forage DMI, DMD or grazing time $(\mathrm{GT})$. Cows on low SH had greater $(\mathrm{P}<.08) \mathrm{DMI}$ and $\mathrm{GT}(\mathrm{P}<.01)$ than cows on high SH. Forage DMI, DMD and GT decreased $(\mathrm{P}<.05)$ with supplementation. Grazing efficiency declined with supplementation and advancing grazing season $(\mathrm{P}<.01)$. Cows consumed more forage $\mathrm{DM}(\mathrm{P}<.01)$ in $\mathrm{P} 1$ and $\mathrm{P} 2$ than $\mathrm{P} 3$. Forage DMI and grazing efficiency decreased with supplementation suggesting that supplemented cattle can optimally be grazed at $\mathrm{SH}<8 \mathrm{~cm}$.
\end{abstract}

Keywords: pasture, sward height, cattle, intake, digestibility, grazing time, supplementation 


\section{ACKNOWLEDGEMENTS}

I would like to express my sincere thanks to the Department of Animal and Vet Science, West Virginia University for financial and material support during my graduate studies. I was very privileged to work with Dr. Edward C. Prigge who served as the chairman of my graduate committee as well as my advisor as an undergraduate student. Dr. Prigge was generous enough to help with field work and every step during the development of this document. I wish to thank Dr. William $\mathrm{H}$. Hoover and Dr. William B. Bryan for willing to serve in my graduate committee. I thank Dr. Edwin C. Townsend for his help with statistics.

I wish to thank Eric Nestor for his help with field work and lab procedures. Sincere thanks to Tammy Miller for her help with protein and $\mathrm{Yb}$ analyses. I deeply appreciate the help that Marcella Schetini (graduate student) and John Bombardiere (work study) gave me in the farm and lab. Last but not least, I would like to thank my wife, children and my parents for their understanding and encouragement which helped me to complete this program. 


\section{TABLE OF CONTENTS}

\section{Page}

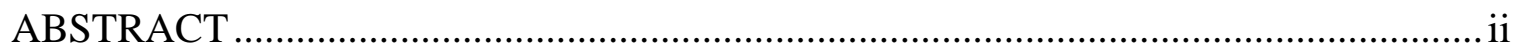

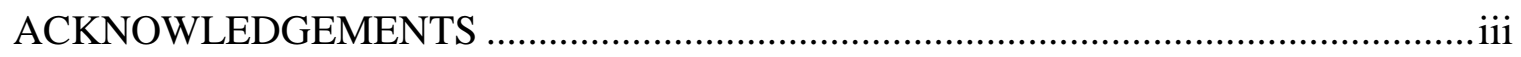

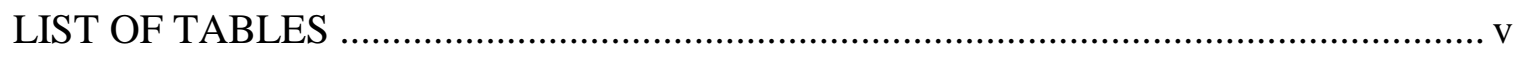

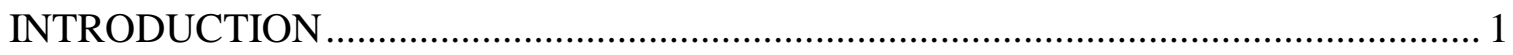

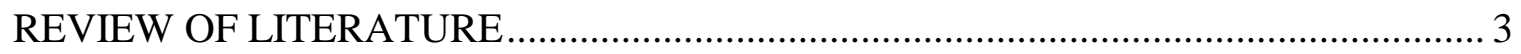

Factors Affecting Forage Intake ................................................................................ 3

Factors Influencing Digestibility in Ruminants ........................................................... 11

Supplementation and Animal Performance................................................................. 13

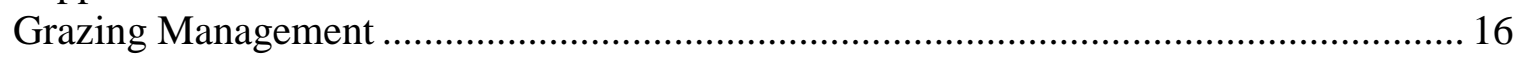

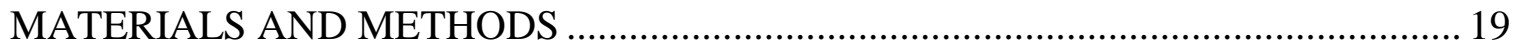

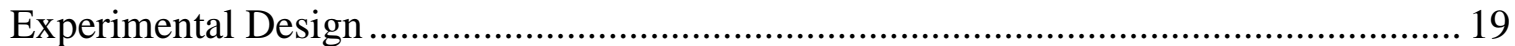

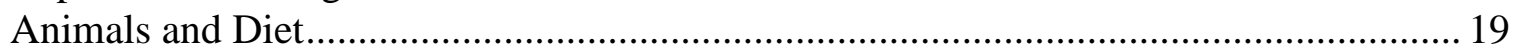

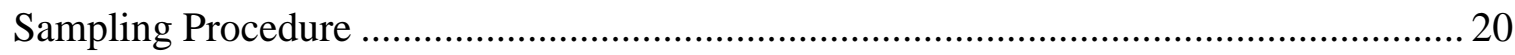

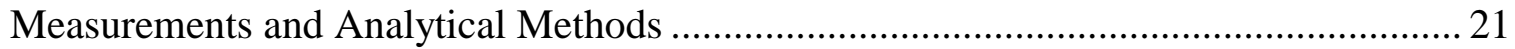

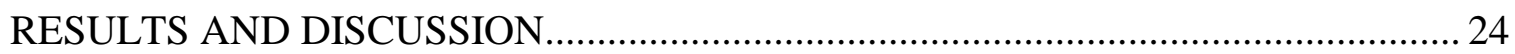

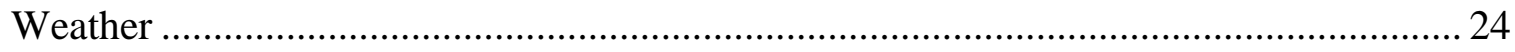

Botanical and Chemical Composition of Pasture ....................................................... 24

Sward Height, Herbage Mass and Carrying Capacity ……............................................. 25

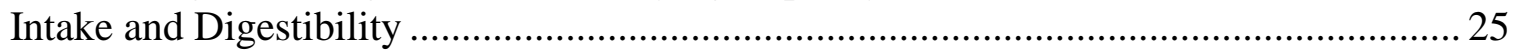

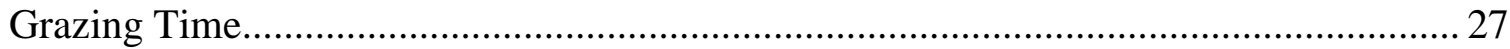

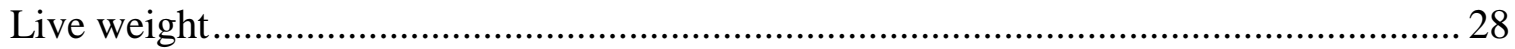

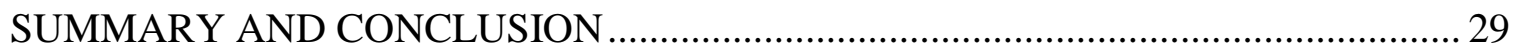

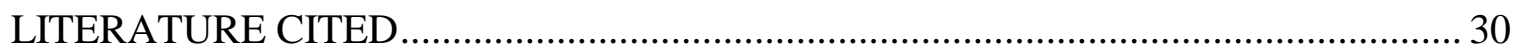

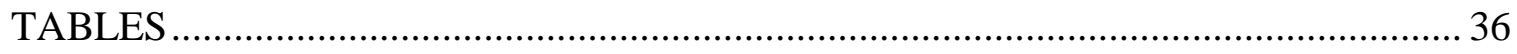

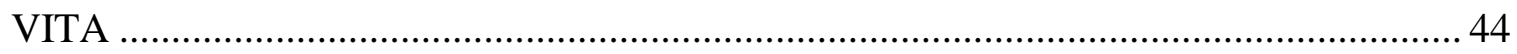

APPROVAL OF EXAMINING COMMITTEE ………………....................................... 45 


\section{LIST OF TABLES}

Table

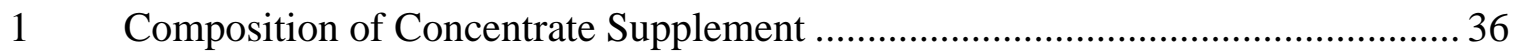

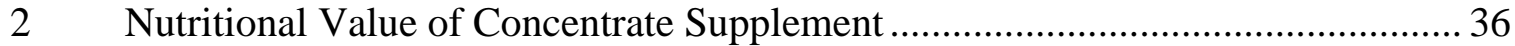

3 Effect of Sward Height on Botanical Composition of Pasture............................. 37

4 Effect of Period on Herbage Growth Rate \& Botanical Composition of Pasture .. 38

5 Effect of Sward Height on Chemical Composition of Pasture............................. 39

6 Effect of Period on Chemical Composition of Pasture ...................................... 39

$7 \quad$ Effect of Sward Height on Animal Performance .......................................... 40

8 Effect of Concentrate Supplement on Animal Performance ............................... 41

$9 \quad$ Effect of Period on Animal Performance ................................................. 42

10 Mean Weekly Minimum and Maximum Temperature and Precipitation .............. 43 


\section{CHAPTER 1: INTRODUCTION}

The height at which a sward is maintained on a pasture can affect forage DMI, behavior (grazing time, rate of bite and intake per bite) and diet digestibility by grazing ruminants (Wright et al., 1990; Rook et al., 1994; Prigge et al., 1997; Cazcarra et al., 1995; Penning et al., 1991). Sward height is negatively correlated with quality attributes; lignification and other fiber components increase with sward height $(\mathrm{SH})$. The proportion of stem and dead material, when compared with the more digestible leaf, increases as SH increases (Van Soest, 1994; Jameison and Hodgson, 1979; Baker et al., 1981a; Wright and Whyte, 1989). Although forage quality may increase as SH decreases, DMI of cattle can decrease as a result of reduced intake per bite and limitations on grazing time (GT) (Hodgson, 1990). Cool season pastures maintained at 8-10 $\mathrm{cm}$ as opposed to lower or higher SH generally provide the best compromise between forage quality and DMI which results in maximum performance of lactating cows (Prigge et al., 1997; Rook et al., 1994; Wright and Whyte, 1989).

Supplementation can increase animal production, especially in high yielding lactating cows (Phillips and Leaver, 1985; Le Du and Newberry, 1982; Rook et al., 1994). On short grass swards, supplementation with concentrates can compensate for decline in forage DMI. Therefore, it is possible that maximum performance of cattle can be obtained at $\mathrm{SH}$ lower than $8-10 \mathrm{~cm}$ with supplementation. However, concentrate supplements may substitute for forage, which may be costly and wasteful (Leaver, 1986). When increased animal performance is desired and SH limits intake, supplementation of pasture with concentrates may be more beneficial than when intake is not limited by SH. Performance of cows grazing high quality pasture maintained at different $\mathrm{SH}$ and concentrate supplement levels has not been documented. Therefore, there is need to investigate the interaction 
between $\mathrm{SH}$ and supplement level and its significance on performance of grazing ruminants. Consequently, the objective of the study was to determine the influence of SH of a cool season pasture and concentrate supplementation on forage DMI, digestibility and GT of spring-calving beef cows and their calves. 


\section{CHAPTER 2: REVIEW OF LITERATURE}

\section{Factors affecting forage intake}

Feed consumption by a grazing ruminant is achieved through a combination of actions initiated by the animal in order to satisfy its nutritional needs. These actions include identification of an appropriate feeding station, initiation of grazing process (prehension, ingestion, mastication of the plant material), swallowing and rumination (Hodgson, 1990). The time an animal stays in a feeding station is affected by quantity of feed to harvest and/or influence from other animals (social facilitation). Forage dry matter intake for a grazing animal depends on a number of animal and forage factors including intake/bite (IB), rate of biting (RB), GT, gut fill, concentrate supplement, immediate environment surrounding the animal, energy demand as well as forage quality and quantity.

I. Animal factors

Animal factors affecting intake on pasture include size, physiological state (age, lactation, and pregnancy); grazing behavior and gut fill (Weston, 1982; Hodgson, 1990).

A. Size and physiological state of animal

In cattle, organic matter intake per kg live weight (LW) decreases with increasing body size. Zoby and Holmes (1983) reported that herbage organic matter (OM) intake for large animals (631 kg BW) was $13 \mathrm{~g} / \mathrm{kg} \mathrm{LW}$ whereas that for young animals (164 kg BW) was $28 \mathrm{~g} / \mathrm{kg} \mathrm{LW}$. The possible reason for the large difference is because young animals have higher nutrient requirements per unit BW. Holmes et al (1962) observed differences between cattle of different weights in digestibility 
and feed intake and concluded that calves had higher digestibility ( 80 vs $72 \%$ on OM basis) compared with older animals grazing a predominantly perennial ryegrass (Lolium perenne L.) sward mixed with white clover (Trifolium repens L.). Intake was $18.1,26.5$ and $31.7 \mathrm{~g} \mathrm{OM} / \mathrm{kg} \mathrm{LW}$ for mature animals, heifers and calves respectively. There was a marked decrease in voluntary intake (VI) per unit BW with advancing age of animals due to change in fasting metabolism (Weston, 1982). Voluntary intake/unit $\mathrm{BW}^{1.0}$ averaged $22 \%$ higher at 8 months of age than at 20 months, and $27 \%$ higher at 8 months than at 32 months when four breeds of sheep were evaluated (Weston, 1982).

Greater body fat has been associated with lower VI in early lactation (-6\% vs rest of lactation period) in dairy cows (Weston, 1982). In late pregnancy (5-6 weeks prepartum), VI decreases by up to $12 \%$ per week in some cases. The reason why VI decreases when demand for energy increases has not been established but some studies hypothesize probable reasons to include the pressure of pregnancy on rumen or abdominal wall distension and metabolic changes inducing limited capacity of the animal to use energy (Weston, 1982). Voluntary intake of forage has been shown to increase by $50 \%$ in lactating dairy cows and up to $26-43 \%$ in lactating ewes during early to mid lactation compared to non-lactating cows (Weston, 1982).

\section{B. Grazing behavior}

Grazing behavior can be defined as a set of actions expressed by an animal in response to stimuli to eat. Grazing behavior is generally discussed in terms of grazing time (GT), rate of biting (RB) and intake per bite (IB). Physiological state and size of the animal, sward characteristics (height, density, quality, palatability and age) and supplementary feed when offered are the main factors influencing grazing behavior. Bite size or IB, RB, and GT markedly affect intake and are greatly influenced by sward conditions such as height and density (Stobbs, 1973). Hodgson (1990) reported that grazing time greater than $8-9 \mathrm{hr} / \mathrm{d}$ is indicative of limiting sward conditions and GT, IB, 
and RB may all decline together if a sward becomes very short. On pasture, young animals have been shown to exhibit a greater degree of herbage selection, smaller bite size, greater number of total bites and more frequent bites than older animals (Zoby and Holmes, 1983).

Sward height can have a major influence on grazing time. Rook et al (1994) reported that sward height and concentrate supplement influenced GT of spring-calving dairy cows grazing a sward of predominantly perennial ryegrass mixed with white clover. Mean daily GT on 6 and $8 \mathrm{~cm}$ sward height (in June) were 10.93 and $10.38 \mathrm{hr} / \mathrm{d}$, respectively, but on a $4 \mathrm{~cm}$ height, GT increased to 12.75 $\mathrm{h}$ when animals were not supplemented and fell to $9.2 \mathrm{~h}$ when animals were supplemented with concentrate at the rate of $4 \mathrm{~kg} / \mathrm{d}$ (Rook et al., 1994). Rumination time averaged $6.2 \mathrm{~h}$ for supplemented cows across the sward height treatments. Rumination time of non-supplemented cows, especially those on $4 \mathrm{~cm}$ sward height, decreased to $4.1 \mathrm{~h}$ because the animals spent more time grazing at the expense of rumination. Idling time remained fairly constant across all treatments.

Grazing time becomes a serious limitation to intake particularly when the sward height falls below a critical height ( $4 \mathrm{~cm}$ for cattle) because prehension is hampered as IB decreases and RB increases (Rook et al., 1994; Baker et al., 1981a). A significant factor limiting intake of grazed herbage is bite size. Bite size tends to decrease as herbage height declines and thus herbage allowance also decreases (Minson, 1990). Declining DM availability, digestibility and increased fecal contamination of the sward may also influence intake (Phillips and Leaver, 1986). Grazing time declines with increasing level of supplemental starch and protein (Krysl and Hess, 1993), although total DM intake may actually increase. Cattle receiving no supplement grazed approximately $1.5 \mathrm{hr} / \mathrm{d}$ more than protein supplemented cattle, resulting in forage intakes of 12.3 and $31.0 \mathrm{~g} \mathrm{OM} / \mathrm{kg}$ body weight for supplemented and unsupplemented cattle, respectively.

The impact of concentrate supplement on GT depends on the amount offered. When cows 
were fed $8 \mathrm{~kg}$ of concentrate, GT declined from $495 \mathrm{~min}$ to $359 \mathrm{~min}$, a mean decline of $22 \mathrm{~min} / \mathrm{kg}$ concentrate or $28 \mathrm{~min} / \mathrm{kg} \mathrm{OM}$ concentrate (Sarker and Holmes, 1974). For each $\mathrm{kg}$ of concentrate eaten there was a corresponding decrease of herbage OM intake of $0.54 \mathrm{~kg}$. Jennings and Holmes (1984) reported that GT declined by 5 and 7\% when dairy cows were supplemented with 4 and $5 \mathrm{~kg}$ of concentrate, respectively.

C. Gut fill and chemostatic effects

Gut fill through the intestinal or rumen distension and chemostatic factors are thought to limit forage intake of cattle (Van Soest, 1994). Whereas satiety is the main factor limiting intake in rations with high caloric density, distension is the main factor limiting intake of lower quality diets (Conrad, 1966). Poor quality feeds or poorly digested feeds that require more retention time for microbial fermentation often result in increased rumen fill. There is sufficient evidence to support the conclusion that fill limits intake through dietary bulk and consequent distension of the digestive tract (Van Soest, 1994). Gut fill has been demonstrated to interact with ruminal tension receptors that feed into the central nervous system to restrict intake or cause eating to cease (Forbes, 1995). Nervous stimulation, hormones and humoral levels of metabolites (volatile fatty acids) are thought to signal the initiation or cessation of eating (Van Soest, 1994). Metabolites acetate and propionate are more effective than butyrate in stimulating the release of hormonal peptides such as cholecystokinin (CCK), particularly from the hypothalamus, that signal cessation of eating (Forbes, 1995).

High dietary digestible energy concentration may limit DMI through an energy feedback mechanism (chemostatic effects) which may result in decreased DMI of diets consisting of concentrates (Barnes et al., 1995). 


\section{Forage factors}

Forage factors affecting intake can be classified into the following groups: (a) physical factors - physical form, leaf vs stem, temperate vs tropical grasses, legumes vs grasses, pasture species and cultivars, (b) chemical factors - quality and composition of fiber and essential nutrients and (c) height of a sward and leaf density.

\section{A. Physical factors}

Intake is related to retention time of feed in the rumen which is affected by feed quality. Feedstuffs that have high fiber content (roughages) require more retention time in the rumen for enhanced microbial fermentation process (Van Soest, 1994). Increased retention time reduces particulate passage rate; consequently, rumen fill sends signals of satiety to which the animal responds by reducing feed intake or cessation of eating. Minson (1990) observed that legumes are more easily broken down during eating and rumination than grasses and have faster passage rates through the digestive tract resulting in higher intake. Voluntary intake of temperate forages is higher than that of tropical forages because the former have a lower fiber content and thus are more digestible (Minson, 1990).

Feed intake increases with increasing rate of herbage digestibility. Legumes have a lower ratio of cell wall material to cell contents than grasses, therefore, both the rate of digestion and amount eaten is higher in legumes than in grasses (Hodgson, 1990). The rate of digestibility of plant tissue declines with increasing herbage maturity (Minson, 1990; Minson, 1982; Hegarty, 1982), consequently, intake also declines. 


\section{B. Chemical factors}

Physiological maturity of forages is associated with increased lignin content. The high concentration of fibrous material in forage (which limits digestibility) is responsible for the lower feeding value of forages compared with grains (Jung, 1989; Van Soest 1994). Intake is inversely related to cell wall constituents and lignin content of the plant (Forbes, 1995; Van Soest, 1994). During plant cell development, primary cell wall (cellulose, hemicellulose and pectin) is deposited initially and lignin becomes incorporated in the cell wall during the formation and thickening of secondary cell wall (Jung, 1989). Lignification of plant cell walls appears to fulfil two main functions: it cements and anchors the cellulose microfibrils together and stiffens the wall and prevents chemical and physical damage to the cell (Akin et al., 1984; Hall et al., 1974).

Covalent linkage of lignin to carbohydrates has been shown to inhibit rumen fermentation which results in reduced particulate passage and increased retention time, the total effect is reduced forage intake (Jung, 1989; Akin, 1982; Van Soest, 1994). Dulphy et al (1980) reported that for 60 $\mathrm{kg}$ sheep, a $1 \%$ increase in crude fiber content of roughages resulted in $38 \mathrm{~g} / \mathrm{d}$ decrease in voluntary feed intake with 0.36 fewer daily meals, $4.1 \mathrm{~min} / \mathrm{d}$ less eating time and $6.6 \mathrm{~min} / \mathrm{d}$ increase in time spent ruminating.

\section{Height of sward and leaf density}

Sward height is a variable that is related to forage quality. Accumulation of indigestible components of cell walls (which limits sward utilization) increases with increasing sward height (Jameison and Hodgson, 1979; Baker et al., 1981b; Wright and Whyte, 1989). Sward surface height (SSH) or the average height of the uppermost leaves in an undisturbed sward canopy as measured by a measuring stick, may influence the rate of forage intake. At SSH of $3 \mathrm{~cm}$, intake rate (IR) and total intake were found to be lower than for taller swards $(6,9$ and $12 \mathrm{~cm})$ for ewes continuously stocked 
on perennial ryegrass swards (Penning and Hooper, 1985). Grazing time was 770, 637, 562 and 533 $\mathrm{min} / \mathrm{d}$ and IR was $2.1,4.8,5.0$ and $4.7 \mathrm{~g} \mathrm{OM} / \mathrm{min}$ at 3, 6, 9 and $12 \mathrm{~cm}$ sward heights, respectively. Based on animal performance, Penning et al (1991) concluded that the optimum SSH for swards continuously stocked with sheep was between 3 and $6 \mathrm{~cm}$. Allden and Whittaker (1970) reported that the size of bite increased almost linearly with increasing tiller length whereas the rate of bite decreased. Therefore, the rate of herbage consumption increased for sheep grazing pastures of 7.7 $\mathrm{cm}$ tiller length as opposed to $3.7 \mathrm{~cm}(7.1 \mathrm{~g}$ and $1.0 \mathrm{~g} \mathrm{DM} / \mathrm{min}$ respectively). When accessibility to herbage imposed limitations on rate of intake the animal responded by increasing GT from 6 to 13 $\mathrm{hr} / \mathrm{d}$.

Although animals may compensate for a reduction in IR by increasing GT, GT may be limited by requirements for ruminating and other non-grazing activities. Gibb et al (1997) observed that Holstein-Friesian cows were unable to increase their GT significantly to when IR was reduced by lower forage availability, as a result daily intake was lower at 5 and $9 \mathrm{~cm}(10.5$ and $12.1 \mathrm{~kg} / \mathrm{d}$ respectively) compared with $7 \mathrm{~cm} \mathrm{SSH}(14.1 \mathrm{~kg})$. Grazing time was 628, 604 and $581 \mathrm{~min} / \mathrm{d}$ for 5, 7 and $9 \mathrm{~cm} \mathrm{SSH}$ respectively.

As $\mathrm{SH}$ increases, the proportion of stem increases and that of the more digestible leaves decreases (Minson, 1990). Intake is dependent on the proportion of green leaf or leafy stem to stem and dead material components of pasture plants (Hodgson, 1990). Leaf is nutritively the most important component of the sward, therefore, leaf yield, \% leaf and bulk density of green material (stem and leaf) are the major sward factors influencing intake by grazing animals (Chacon and Stobbs, 1976). Low leaf density influenced diet selection by cattle grazing Setaria anceps cv. kazungula grass swards, the proportion of leaf in diet selected declined from 90 at turn out to 56 and $59 \%$ in autumn and spring respectively (Chacon and Stobbs, 1976). Swards incorporating a low stem 
content and high leaf/height ratio appeared to influence the size of bite taken by cows grazing tropical pastures (animals prehended the sward more easily). Stobbs (1973) concluded that a mean bite size below $0.3 \mathrm{~g}$ OM could seriously limit daily intake of herbage by grazing animals.

D. Moisture content

Forages have high moisture content early in the grazing season (spring) or early in the rainy season (tropics). The high moisture content in forage has been associated with depressed feed intake and reduced digestibility (Pasha et al., 1994). Voluntary intake in sheep was restricted when the DM content of pasture was <25\%, this directly affected weight gains (Arnold, 1962; Butris and Phillips, 1987). Grant et al (1976) showed the significance of high moisture content in forages fed to cattle when they fed wilted vs wet napier grass (Pennisetum purpureum Schum.) and found that wilting markedly increased intake (2.3\% vs $2.2 \%$ of BW) and DM digestibility (73.2\% vs $68.6 \%)$.

\section{E. Essential nutrients}

In addition to energy, $\mathrm{N}$ is essential for microbial growth. Intake can be depressed when protein concentration of a forage falls below $8-10 \%$ because inadequate supply of $\mathrm{N}$ results in depressed microbial fermentation (Siebert and Hunter, 1982; Armstrong, 1982). Excess protein in the diet results in increased heat production due to deamination of excess amino acids (Armstrong, 1982). Increased heat dissipation and rise in body temperature depresses feed intake (Blaxter and Wilson, 1963; Elliot and Topps, 1963). Early in lactation, intake of dairy cows can be increased by increasing the protein content of feed on offer and/or use of leguminous shrubs e.g. leucaena (leucaena leucocephala L.) especially in arid areas where feed of high quality is scarce (Muinga et al., 1992). Deficiency of essential minerals e.g. Ca, P, Mn, Mg, and vitamins can depress forage intake as reviewed in NRC (1989). 


\section{Factors influencing digestibility in ruminants}

Forage utilization by ruminant animals is largely dependent on digestibility and absorption of the main organic constituents available in the feed consumed (carbohydrates, $\mathrm{N}$ and fats). Solubility and absorption of the inorganic constituents $(\mathrm{Ca}, \mathrm{P}, \mathrm{Na}, \mathrm{Mg}$ ) is also important (Hodgson, 1990). The retention time of feed in the rumen, which depends on particulate passage rate, is a crucial factor influencing digestibility in ruminant animals. Therefore, digestibility is a function of competition between digestion and passage rate (Van Soest, 1994). Digestibility is influenced in part by forage type and forage quality.

\section{Forage type}

Wilson et al (1983) reported that gross differences in tissue proportions between $\mathrm{C}_{4}$ (tropical) and $\mathrm{C}_{3}$ (temperate) grasses is the important factor contributing to general differences between them in digestibility. Dry matter digestibility (DMD) was 76, 70 and 69\% and cell wall content was 33, 42 and $50 \%$ respectively for $\mathrm{C}_{3}, \mathrm{C}_{3} / \mathrm{C}_{4}$ (hybrid) and $\mathrm{C}_{4}$ grasses (Panicum species). Other than different photosynthetic pathways, $\mathrm{C}_{4}$ species have thick-walled specialized cells surrounding the vascular tissue, have more vascular bundles and less of the readily digestible mesophyll cells. Thus $\mathrm{C}_{4}$ grasses have a higher proportion of parenchyma bundle sheath, epidermis, vascular tissue and scelerenchyma tissue which are either poorly digestible or indigestible (Akin, 1982). Legumes have lower resistance to breakdown during eating and rumination compared to grasses because legumes are characterized by low cell wall and high protein contents (Minson, 1990; Van Soest, 1994). Grasses tend to be relatively high in cell wall and low in lignin but the lignification affects a larger proportion of available digestible matter in grasses than in legumes. Due to the high cell wall 
content, retention time is greater in grasses than in legumes (Van Soest, 1994; Minson, 1990).

\section{Forage quality}

Akin (1989) observed that physical structures in plant leaves and stems which vary with plant parts, type and species, and growth conditions, limit forage degradation by ruminants. Akin (1989) further reported that plant anatomy influences digestibility as well as particle size and shape after mastication. The stem anatomy in grasses is generally a rigid structure with rows of lignified cells that are indigestible and present a barrier to digestion and physical destruction (Akin et al., 1984). Cell wall concentration is normally greater in stems than in leaves, whereas leaves are usually more digestible than stems (Hodgson, 1990). Albrecht et al (1987) observed that changes in proportion of cell wall material as seen in maturing alfalfa (Medicago sativa L.) affected digestibility. Concentration of in vitro DMD in leaves changed little (approximately $800 \mathrm{~g} / \mathrm{kg}$ ) whereas that of stems declined from $750 \mathrm{~g} / \mathrm{kg}$ before bud development to $480 \mathrm{~g} / \mathrm{kg}$ as plants matured. Digestibility of alfalfa declined with maturation due to increased cell wall material in stems, decreased stem digestibility and increased proportion of stems (Albrecht et al., 1987).

Griffin and Jung (1983) reported that with increasing maturity, neutral detergent fiber (NDF) and lignin were greater in stems than leaves of bluestem (Andropogon gerardi Vitman) and switch grass (Panicum virgatum L.), fiber accumulation continued after seed heads emerged and was accompanied by decreases in CP and IVDMD. Forage quality seems to decline with progressive defoliation as the season advances. Chacon and Stobbs (1976) observed that mean OM digestibility of pasture on offer (Setaria anceps cv. kazungula) declined with progressive defoliation: 58.6, 51.9 and $20.2 \%$ for leaf, stem and dead material, respectively, at start of experiment (spring) to $57.4,45.5$ and $19.3 \%$ at the end of the experiment (autumn). Nitrogen content also declined with progressive 
defoliation. This decline was mostly related to the increased proportion of stem as cattle selected the readily digestible leaf.

\section{Supplementation and animal performance}

Supplements are offered to grazing animals to maintain or improve animal performance. Energy supplements often substitute for the intake of herbage and therefore stocking rates can also be increased (Leaver, 1986).

I. Forage supplements on pasture

Forage supplements (hay, silage) are fed to ruminant animals at times of feed shortage or to supply extra nutrients that the animals need and cannot get from the daily herbage allowance. High quality hay supplements (e.g. alfalfa hay) supply deficient nutrients to grazing animals, especially high yielding cows. By offering a hay supplement for 45 min daily, total DM intake, milk yield (early in the season) and live weight gain (late in the season) increased in continuously stocked spring-calving cows (Phillips and Leaver, 1985). Depending on palatability, quality and quantity on offer, forage supplements may end up substituting for rather than supplementing grazed herbage. Phillips and Leaver (1985) observed that offering grass silage to dairy cows depressed grazed herbage DM intake but had no effect on total DMI. Grazing times were shorter in supplemented compared with non-supplemented cows. Due to declining sward height late in the season, GT increased as bite size decreased below $0.3 \mathrm{~g} \mathrm{OM}$, rate of biting increased and pasture DM intake was lower compared to early in the season, consequently, silage supplementation increased milk yield (Phillips and Leaver, 1985). 


\section{Concentrate supplement on pasture}

Concentrate supplementation is used to supply additional nutrients (mainly energy) to grazing animals with the hope of increasing production. In a review by Leaver (1985), most experiments have reported that concentrate supplementation has minimal effect on milk yield $(0-0.4 \mathrm{~kg} / \mathrm{kg}$ concentrate) but others have reported yield increases of 2.2 to $3.3 \mathrm{~kg} / \mathrm{kg}$ concentrate averaged over the whole lactation period. Greater responses have been realized during times of inadequate herbage supply (or drought) or when herbage allowance is restricted, and those are the times when supplementation with energy becomes useful.

Jennings and Holmes (1984) reported that dairy cows increased total OM intake, milk yield and live weight gain by $0.85,0.55$ and $0.45 \mathrm{~kg} / \mathrm{d}$ respectively for each $\mathrm{kg}$ of concentrate fed. In grazing dairy cows undergoing a period of pasture restriction, concentrate supplement ( $3 \mathrm{~kg} / \mathrm{d}$ for 2 weeks or $2 \mathrm{~kg} / \mathrm{d}$ for 5 weeks) resulted in an immediate increase in milk yield of 1.0 and $1.9 \mathrm{~kg}$ milk/kg concentrate, respectively. Control cows had a pasture allowance of $50 \mathrm{~g} \mathrm{DM} / \mathrm{kg}$ LW whereas restricted cows were allowed $25 \mathrm{~g} \mathrm{DM} / \mathrm{kg} \mathrm{LW}$. The overall response was 2.9 and $3.5 \mathrm{~kg} \mathrm{milk} / \mathrm{kg}$ concentrate, respectively (Le Du and Newberry, 1982).

Herbage intake by animals supplemented with concentrate depends on herbage allowance and level of concentrate supplemented. Meijs and Hoekstra (1984) reported that the effect of concentrate supplement $(0.8,3.2$ and $5.6 \mathrm{~kg} \mathrm{OM} / \mathrm{d})$ on herbage $\mathrm{OM}$ intake was affected by daily herbage allowance. At low herbage allowance (16 kg OM/d), intake was 10.9, 10.6 and $10.4 \mathrm{~kg} \mathrm{OM} / \mathrm{d}$, respectively, whereas at high allowance $(24 \mathrm{~kg} \mathrm{OM} / \mathrm{d})$, intake was $14.8,13.6$ and $12.4 \mathrm{~kg} \mathrm{OM} / \mathrm{d}$, respectively. The mean substitution rate was 0.1 and 0.5 , respectively, for low and high herbage allowances. Substitution rate refers to the amount of decline in forage OM intake $(\mathrm{kg})$ per $\mathrm{kg}$ OM supplement fed. Le Du et al (1979) reported that in two 6-week feeding periods supplementary 
concentrates $(5.2 \mathrm{~kg} \mathrm{DM} / \mathrm{d})$ depressed daily herbage intake in dairy cows by 0.25 and $0.62 \mathrm{~kg} / \mathrm{kg}$ concentrate DM offered. Milk yield for supplemented cows increased by 0.8 and $0.5 \mathrm{~kg} / \mathrm{kg}$ concentrate over the respective periods compared with non-supplemented cows (control). In an earlier period during the same study, supplementation with concentrates did not depress intake and milk yield increased by $1.0 \mathrm{~kg} / \mathrm{kg}$ concentrate (Le Du et al., 1979).

Concentrate supplementation (4 kg OM/d) significantly increased total intake (13.4 vs 17.6 $\mathrm{kg} \mathrm{OM} / \mathrm{d}$ ) and milk yield (24.0 vs $26.4 \mathrm{~kg} / \mathrm{d}$ ) in cows grazing perennial ryegrass (Lolium perenne $\mathrm{L}$. ) pastures. The supplement produced an overall direct response of $0.6 \mathrm{~kg}$ milk/ $/ \mathrm{kg}$ concentrate (Jennings and Holmes, 1984). Rook et al. (1994) reported that when spring-calving dairy cows grazing perennial ryegrass-white clover sward were supplemented with $4 \mathrm{~kg} \mathrm{DM} / \mathrm{d}$ concentrate, milk yield increased by $1.12 \mathrm{~kg} / \mathrm{kg}$ concentrate in period 1 (June) and $0.87 \mathrm{~kg} / \mathrm{kg}$ concentrate in period 2 (July/August). Three sward height treatments $(4,6$ and $8 \mathrm{~cm})$ were imposed in period 1, with no major difference in response of milk yield to supplementation being observed although cows on $4 \mathrm{~cm}$ sward suffered substantial weight loss. Individual animal milk yields were similar between cows on 6 and $8 \mathrm{~cm}$ swards (4 $\mathrm{cm}$ sward was not used in period 2) during period 2. Therefore, grazing a sward to a height of $6 \mathrm{~cm}$ combined with concentrate supplement offers advantages in terms of animal output/ha compared with either higher or lower sward heights.

Both forage and concentrate supplementation of grazing ruminant animals have beneficial effects on animal performance particularly during periods of inadequate supply of good quality forage. However, supplementation may be both costly and wasteful if it substitutes rather than add to good quality forage especially with low producing animals or dry non-pregnant animals. 


\section{Grazing management}

Grazing management is a set of decisions made to ensure grazing animals have access to an ample supply of good quality forage throughout the season. The goal of these decisions is to maintain an appropriate stocking rate and forage availability in order to optimize animal production. The goal of the producer is to ensure optimum production of both animals and forage per unit area while maximizing profits.

\section{Stocking rate}

Stocking rate refers to the number of animals per unit area of pasture (e.g. 3 cows/ha). Optimum stocking rate is important in animal and pasture production systems and can affect performance of both if not applied appropriately (Hodgson, 1990). Baker et al (1981b) observed the response of cow/calf units to changes in severity of grazing induced by set-stocking pastures at different stocking rates. Increasing the stocking rate from low (3.33/ha) to medium (3.81/ha) reduced daily milk yield, cow and calf live weight gains by $1.1,0.14$ and $0.09 \mathrm{~kg} / \mathrm{d}$, respectively, and from medium to high (4.44/ha) by 1.3, 0.24 and $0.03 \mathrm{~kg} / \mathrm{d}$. Live weight output for calves was 628,658 and $743 \mathrm{~kg} / \mathrm{ha}$ for low, medium and high stocking rates, respectively, and corresponding cow output was 246,179 and $30 \mathrm{~kg} / \mathrm{ha}$, respectively. It was generally concluded that pasture management decisions should be based on cow rather than calf performance since the calf is buffered against the effects of herbage allowance by milk received from the cow (Baker et al., 1981b). 


\section{Sward management}

Good sward management should maximize herbage mass/unit area, supply forage of high nutritive value and high tiller density, and should sustain a sward which can withstand a high defoliation rate throughout the season.

Use of fertilizer is a management practice commonly used to increase forage productivity (quality and quantity) throughout the grazing season. Nitrogenous fertilizer improves the $\mathrm{CP}$ content of some forages resulting in increased VI of up to $70 \%$, but this effect may be related to stage of maturity (Minson, 1990).

Regrowth of a sward following defoliation depends on frequency, intensity and timing of defoliation. Frequency refers to time intervals between successive defoliations, intensity refers to severity of defoliations. Timing of defoliation is considered in relation to developmental phases of plants and season of the year (Harris, 1978). Severe defoliation which may involve removal of growing points and treading of a sward requires a longer recovery period especially late in the grazing season when growth rate is slow. Regrowth period may also depend on the growth habit of the sward (Pearson and Ison, 1997), trailing plants require more recovery time after defoliation, which may influence the choice of grazing system adopted. Time required for regrowth of a sward to a height that provides optimal herbage mass, quality and animal performance, varies with prevailing weather conditions, canopy tissue demography (leaf, stem, and senescence tissue), nutrient availability, residual height after defoliation, developmental stage and other management factors (Belesky and Fedders, 1994).

Mayne et al (1987) demonstrated that grazing intensely early in the season (e.g. to $6 \mathrm{~cm}$ sward height) resulted in better sward structure late in the season and improved grassland utilization. They concluded that in a rotational grazing system, a reasonable compromise between sward utilization and 
animal performance could be achieved by grazing spring-calved dairy cows to a residual sward height of $6 \mathrm{~cm}$. Bryan and Mills (1988) observed that more herbage was produced from a Kentucky blue/white clover sward cut to simulate rotational regrowth (4-wk regrowth interval) than from a sward managed for hay. Repeated defoliation (50\% and 70\% removal) of orchard grass, tall fescue (Festuca arundinacea L.) x perennial ryegrass hybrid and prairie grass (Bromus unioloides L.), based on sward height and not other considerations (time interval, stocking rate) resulted in more stable distribution but less herbage within a season, compared with canopies managed as hay (Belesky and Fedders, 1994).

Herbage allowance refers to the quantity of herbage allotted to the animal for a certain period. When herbage allowance is less than what the animal will voluntarily consume, increasing herbage allowance increases intake until a point is reached when intake is at a maximum, regardless of the amount on offer, thus the relationship between allowance and consumption appears to be curvilinear (Greenhalgh et al., 1966).

Grazing management strategies should include appropriate stocking rate, good sward management (weed control, fertilizer use, sward height, defoliation intensity) and an appropriate grazing system which emphasizes optimum animal performance, pasture quality, availability and stability throughout the year. Possible SH x concentrate supplementation interaction on forage utilization of grazing cattle needs to be investigated. The results may establish the optimum level of each factor that could maximize animal performance while maintaining pasture stability. 


\section{CHAPTER 3: MATERIALS AND METHODS}

\section{Experimental Design}

The experiment was conducted at the West Virginia University Animal Science Farm, Morgantown, during the 1996 grazing season. The experimental area has a slope of 15-20\%. Soil types were: Clarksburg (fine-loamy, mixed, mesic Typic Fragiudalfs); Dormont (fine-loamy, mixed, mesic ultic Hapludalfs) and Holly (fine-loamy, mixed, non acid, mesic Typic Fluvaquents). No lime or fertilizer were applied. Twenty four multiparous crossbred Angus beef cows (535 kg BW) calving between February 1 and April 1 and their calves (114 kg BW) were grouped according to calving date and body weight. They were randomly assigned two SH treatments $(4-8$ or 8-11 cm) replicated four times. Each cow received one of the three levels of concentrate supplement: no supplement $(0 \mathrm{~kg})$, low supplement $(3.12 \mathrm{~kg})$ and high supplement $(6.24 \mathrm{~kg})$ per day, referred to as $\mathrm{U}$, $\mathrm{L}$, and $\mathrm{H}$, respectively. The experiment was conducted over three periods, each lasting 15 days: May 14 - May 28 (period 1), June 25 - July 9 (period 2) and August 7 - August 21 (period 3). Each cow was assigned to a different level of supplement during each of the three periods. The experimental cow/calf units grazed on the same plots during all three experimental periods.

\section{Animals and Diet}

Before the start of period 1, all animals were fitted with fly control ear tags (Cutter blue, Bayer Corp., Shawnee, KS) and treated for internal parasites using Safe-Guard (Hoechst Roussel Vet, Sommersville, NJ). The University Animal Care and Use Committee approved management of animals and experimental procedures. Animals were weighed at the beginning and end of each experimental period. Cows were fed the supplements individually in $2.5 \mathrm{~m}$ x $0.8 \mathrm{~m}$ stalls located within each plot. The stalls also were used for placement and removal of vibracorders, feeding of 
a fecal output marker and collection of fecal samples.

The concentrate supplement was offered in two equal portions at $700 \mathrm{~h}$ and $1900 \mathrm{~h}$. The supplement was comprised of corn, soybean meal and limestone (Table 1) and its nutritive value (Table 2) was estimated from standard feed composition tables (NRC, 1989). Animals were allowed free access to a trace mineralized salt block ${ }^{1}$ (Morton International, Inc. Chicago, IL) and water. The pasture was comprised of grasses, predominantly Kentucky bluegrass (Poa pratensis L.) and some orchardgrass (Dactylis glomerata L.); legumes, predominantly white clover (Trifolium repens L.) and some red clover (Trifolium pratense L.); weeds were mainly broad-leaved. Non-experimental yearling cattle of similar breeding as the cows were used to maintain the swards at the desired heights. Appropriate adjustments in cattle numbers were made weekly to maintain the desired sward heights. Between periods, the experimental cow-calf units were moved to non-experimental pastures of similar type.

\section{Sampling Procedure}

Botanical composition and growth rate $(\mathrm{kg} / \mathrm{ha} / \mathrm{d})$ of pasture were determined from clip samples cut biweekly within four exclusion cages measuring 1.2 x $1.2 \mathrm{~m}$ and on four other close-by areas randomly located within each plot. The exclusion cages were moved at random to new locations within the plots after each sampling. The forage samples were cut close to ground level using $10.2 \mathrm{~cm}$-wide battery-powered grass shears and frozen $\left(-20^{\circ} \mathrm{C}\right)$ until the time of sorting and separation. Samples were thawed at room temperature $\left(22^{0} \mathrm{C}\right)$ then hand separated into grass, legume, weeds and dead material and visible soil removed. The samples were dried in an oven $\left(80^{\circ} \mathrm{C}\right)$ to a constant weight and allowed to cool before weighing. To monitor pasture conditions, $\mathrm{SH}$ measurements (50 readings/plot) were taken weekly using an acrylic plastic meter as described by

${ }^{1} 95-98 \% \mathrm{NaCl}, 0.35 \% \mathrm{Zn}, 0.28 \% \mathrm{Mn}, 0.175 \% \mathrm{Fe}, 0.035 \% \mathrm{Cu}$, and $0.007 \% \mathrm{Co}$ 
Rayburn and Rayburn (1998). Only measurements collected during the experimental period are reported in this experiment.

Pluck samples of forage, representing the grazed horizon, were taken from each plot every two days starting d 9 through 13 of each period for determination of chemical composition and for estimation of DMI and digestibility. To obtain pluck samples, four individuals (two per four plots) collected multiple samples from observed grazing areas until a sample of approximately $500 \mathrm{~g} \mathrm{had}$ been collected from each plot. The samples were bulked by plot during each period.

A small portion of the supplement (100 g) was mixed with Yb-labeled oats offered to U level cows to encourage consumption. A fecal grab sample of approximately $300 \mathrm{~g}$ was collected from the rectum of each cow in the morning and evening to coincide with supplement feeding on $\mathrm{d} 10$ through 14. Samples of plucked forage, supplement, Yb-labeled oats and feces were composited, dried at $80^{\circ} \mathrm{C}$ to constant weight and ground in a Wiley mill (Thomas Scientific, Swedensboro, NJ) to pass through a 1-mm screen. Samples were subsequently analyzed for crude protein $(\mathrm{CP})$, neutral detergent fiber (NDF), acid detergent fiber (ADF), alkaline peroxide lignin (APL), and Ytterbium ( $\mathrm{Yb}$ ) concentration.

\section{Measurements and Analytical Methods}

Weather data as reported by the National weather station, Hart Field Airport, Morgantown, WV, was summarized over the grazing season (Table 10). Sward height measurements were made using an acrylic plastic disc meter (Rayburn and Rayburn, 1998). To allow comparison with other investigations, SSH using the Hill Farming Research Organization (HFRO) sward stick (Barthram, 1986) was calculated from the SH. The following prediction equation, developed from paired samples (SH and SSH) taken on experimental pastures in 1995 using the method of Bryan et al (1990), was used: 


$$
\mathrm{SSH}(\mathrm{cm})=1.1851 \times \mathrm{SH}(\mathrm{cm})-0.6011, \mathrm{R}^{2}=0.90
$$

The relationship between sward height and herbage mass was estimated from the following equation developed from paired samples (plate height and herbage DM) taken on experimental pastures in 1992, 1993, and 1995 using the method of Bryan et al (1990).

$$
\text { Herbage mass }(\mathrm{kg} / \mathrm{ha})=231.48 \times \mathrm{SH}(\mathrm{cm})-81.91, \mathrm{R}^{2}=0.80
$$

Herbage growth rate was estimated within exclusion cages over $2-4$ week growth cycles. The following formula was used to estimate daily herbage growth rate:

Herbage growth rate $(\mathrm{kg} / \mathrm{ha} / \mathrm{d})=$

Herbage mass at end $(\mathrm{kg} / \mathrm{ha})$ - Herbage mass at start $(\mathrm{kg} / \mathrm{ha})$

$$
\text { Length of growth cycle (days) }
$$

Dry matter and CP were analyzed according to procedures described by AOAC (1990). Neutral detergent fiber (NDF) was analyzed following procedures described by Van Soest et al (1991). Acid detergent fiber was determined according to procedures described by Robertson and Van Soest (1981). In vitro dry matter digestibility (IVDMD) of the supplement was determined as described by Goering and Van Soest (1970), using a ruminal fluid inoculum obtained from a ruminally cannulated steer grazing a similar type of pasture.

Ytterbium (Yb) was used as an external indicator to measure fecal output. For preparation of the $\mathrm{Yb}$-marked oats, oats grain was sprayed with a solution of $\mathrm{YbCl}_{3} \cdot 7 \mathrm{H}_{2} \mathrm{O}$ and water as described by Baker et al (1988). Each cow received $100 \mathrm{~g}$ of Yb-labeled oats/d starting day 1 of each period (50 $\mathrm{g}$ at each feeding). Samples of the composited feces and labeled oats were analyzed for $\mathrm{Yb}$ concentration according to procedures of Baker et al (1988). Fecal output (DM basis) was calculated from indicator concentrations using the following formula:

Fecal output $(\mathrm{kg} /$ day $)=$

Indicator dose, $\mathrm{mg} /$ day

$$
\overline{\text { Indicator concentration in feces, } \mathrm{mg} / \mathrm{kg}}
$$


The contribution of pasture to fecal output was estimated by subtracting the IVDMD indigestible fraction of supplement from the total fecal output using the following formulas:

Suppl. fecal output, $\mathrm{kg} / \mathrm{day}=($ Suppl. intake, $\mathrm{kg} / \mathrm{day}) \times(1-$ Suppl. IVDMD $)$

Forage fecal output, kg/day $=($ Fecal output, kg/day $)-($ Suppl. fecal output, $\mathrm{kg} / \mathrm{day})$

The alkaline peroxide lignin (APL) content of pasture and feces was used as an internal marker to estimate intake as reported by Sunvold and Cochran (1991), using the following formula:

Forage DMI (kg/day) =

(APL in feces, $\mathrm{kg} / \mathrm{d})-($ APL in suppl., $\mathrm{kg} / \mathrm{d})$

\section{APL content in forage}

Forage digestibility was calculated using the following formula:

$$
\text { Forage digestibility }(\%)=\frac{(\text { Forage DMI, } \mathrm{kg} / \mathrm{d})-(\text { Forage fecal output, } \mathrm{kg} / \mathrm{d})}{\text { Forage DMI }(\mathrm{kg} / \mathrm{d})} \times 100
$$

Grazing time (GT) was measured using vibracorder equipment (Kienzle Apparate Gmbh, Villingen, Germany) fitted around the neck of each cow during each experimental period. The vibracorder remained on the animal for a period of $48 \mathrm{~h}$. An animal was considered either grazing or ruminating/idling if it spent at least 5 continuous minutes doing this activity.

Results of this study were analyzed according to SAS (1985) using analysis of variance (ANOVA) based on a split plot design with sward height as the main plot. Each subplot was a $3 \mathrm{x}$ 3 Latin square with cow, supplement level and period as the factors. Significant $F$ test $(\mathrm{P}<.10)$ was used to determine the effect of sward height, supplement level and period on forage DMI, digestibility, grazing time, and weight gain of animals. Sums of squares for supplement were compared in two orthogonal comparisons. 


\section{CHAPTER 4: RESULTS AND DISCUSSION}

\section{Weather}

Mean weekly maximum and minimum temperatures together with total weekly precipitation are shown in the Table 10. Mean temperature and precipitation were normal for this area over the experimental periods. Ambient temperatures were lower for period 1 compared to periods 2 and 3, which is considered normal seasonal variation.

\section{Botanical and chemical composition of pasture}

There was no two-way interaction $(\mathrm{P}>.10)$ between $\mathrm{SH}$ and period for botanical composition of pasture. Sward height did influence $(\mathrm{P}<.09)$ botanical composition of pasture (Table 3), with the proportion of grass decreasing by approximately $5 \%$ and dead material increasing by approximately $7 \%$ for the high compared to the low SH. Forage accumulation resulting in increased maturity and senescence, probably contributed to the high proportion of dead material for the higher SH. Leaves attain senescence within a short period of time, usually 3 weeks (Hodgson, 1990). Sward height did not influence $(\mathrm{P}>.10)$ the proportion of weeds and legume. Period influenced $(\mathrm{P}<.01)$ the proportion

of grass in the sward (Table 4). Grass content was lower by approximately $10 \%$ during P2 compared to other periods. During P2, the proportion of legume tended to increase at the expense of grass $(\mathrm{P}=.11)$ probably because of the seasonal growth patterns of these forage types.

Sward height influenced $(\mathrm{P}<.10)$ the $\mathrm{CP}$ and NDF contents of pasture (Table 5). Crude protein decreased whereas NDF increased as SH increased, as would be expected with more mature swards (Minson, 1990; Van Soest, 1994). Both NDF and ADF contents of pasture increased $(\mathrm{P}<.01)$ as season progressed partly because the growth rate of herbage declined (Table 4) with season, accelerating herbage maturity which can increase fiber content (Van Soest, 1994). 


\section{Sward height, herbage mass and carrying capacity}

Mean sward height for the low and high swards as determined by the method of Rayburn and Rayburn (1998) and by the HFRO sward stick (Barthram, 1986) as well as herbage growth rate and the corresponding herbage mass are shown in Table 3. The two measurements for SH were included to allow for comparison with other literature on the subject. Sward height did not influence $(\mathrm{P}>$.10) herbage growth rate (Table 3). In a previous study on the same pasture, carrying capacity per ha increased as $\mathrm{SH}$ decreased from 12 to $4 \mathrm{~cm}$ as measured by the HFRO sward stick (Prigge et al., 1997), indicating that stocking density was increased. In the present study, herbage growth rate decreased $(\mathrm{P}<.03)$ as season progressed (Table 4$)$ which is considered to be normal due to temperature and moisture limitations on growth rate of cool season grasses (Pearson and Ison, 1997).

\section{Intake and digestibility}

There were no three-way interactions ( $\mathrm{P}>.10)$ of $\mathrm{SH} x$ supplement level x period or two-way interaction between SH and supplement level for total DMI, forage DMI and digestibility. Sward height, however, did influence $(\mathrm{P}<.08)$ total DMI and forage DMI. Cows on the lower SH consumed $0.61 \mathrm{~kg} / \mathrm{d}$ more total DM and a similar amount of forage DM than those on the higher sward (Table 7) most likely because of lower NDF concentration and increased grazing time. Our results differ from those of Cazcarra et al (1995) who concluded that herbage intake from orchard grass is limited at mean sward heights below $8 \mathrm{~cm}$ (rising plate meter height), our results show that forage DMI was higher on pastures grazed lower than $8 \mathrm{~cm}$ (Table 7). Demment and Greenwood (1988) suggested that there is less mastication at lower sward densities (lower $\mathrm{SH}$ ), animals can thus increase intake rate and achieve higher rumen fill and perhaps better digestible energy yield, our results generally agree with their conclusion in regard to DMI. Sward height had no $(\mathrm{P}>.10)$ influence on forage digestibility. 
Supplement level influenced total DMI, forage DMI and forage digestibility $(\mathrm{P}<.01)($ Table 8). Cows on $\mathrm{H}$ level of supplement consumed $1.14 \mathrm{~kg} / \mathrm{d}$ more total $\mathrm{DM}(\mathrm{P}<.08)$ than nonsupplemented cows. However, non-supplemented cows consumed 2.21 and $4.87 \mathrm{~kg} / \mathrm{d}$ more forage $\mathrm{DM}(\mathrm{P}<.05)$ than $\mathrm{L}$ and $\mathrm{H}$ cows, respectively. The reason why supplemented cows consumed more total DM may be due to decreased inhibition of gut fill on voluntary intake (Forbes, 1995; Van Soest, 1994) and increased intake of the more digestible DM. However, forage digestibility was higher $(\mathrm{P}<.01)$ in non-supplemented compared with supplemented cows whereas cows on $\mathrm{L}$ supplement had higher $(\mathrm{P}<.05)$ forage digestibility than those on $\mathrm{H}$ (Table 7$)$. Levels of readily fermentable carbohydrates (RFC) greater than $30 \%$ of total DMI have been reported to depress fiber digestibility (Hoover, 1986). Reasons for the depressive effects of concentrates on fiber digestibility include decrease in ruminal $\mathrm{pH}$, competition for essential nutrients which seems to favor RFC digesting microbes, and preference by microbes for RFC over fiber components (Mould and Orskov, 1984). One or all of the depressive effects possibly caused the reduced fiber digestibility with supplementation observed in this study. Concentrate supplement contributed $29 \%$ and $56 \%$ of the total DMI of $\mathrm{L}$ and $\mathrm{H}$ cows respectively. In spite of decreased intake and digestibility of forage as the level of supplementation increased, total digestible DMI (table 8) was greater for the supplemented cattle suggesting a superior level of performance for these cattle could be realized.

Period had an effect on total DMI and forage DMI $(\mathrm{P}<.01)$. Cows consumed $2.35 \mathrm{~kg} / \mathrm{d}$ more total DM and a similar amount of forage DM during P1 and P2 compared with P3 (Table 9). High environmental temperature, declining forage quality and quantity, and a lower level of milk production were probable contributing factors to the lower intake for P3. 


\section{Grazing time}

There was no interaction $(\mathrm{P}>.10)$ between $\mathrm{SH}$, supplement level and period or between $\mathrm{SH}$ and supplement level on GT. Sward height did influence $(\mathrm{P}<.01)$ GT, cows on the lower sward height spent more time grazing (1.25 hours/d) compared with those on higher sward (Table 7). The probable reason for increased GT is that intake per bite declines as sward height decreases (Rook et al., 1994; Penning et al., 1991). Cows responded to decreased SH by allocating more time to grazing activity probably to compensate for reduced bite size. Forage DMI/hour of GT was not different $(\mathrm{P}>.10)$ between the sward heights. The herbage quality of high $\mathrm{SH}$ pastures was lower $(\mathrm{P}<.10)$ compared to low SH pastures, possibly limiting GT by increasing rumination time or gut fill effects as opposed to less efficient grazing.

Decreased forage DMI/hour of GT $(\mathrm{P}<.01)$ as supplement level increased was observed (Table 8) and is indicative of decreased intensity of grazing when supplement was fed. Cows on L supplement level spent an additional 0.5 hour/d grazing $(\mathrm{P}<.05)$ compared with those on $\mathrm{H}$ level. Leaver (1986) reported that when supplements were fed to cows, there was a reduction in GT of 3-20 min/kg supplement DM depending on sward condition. In our study, reduction in GT was 2-8 min/kg supplement DM, generally in agreement with Leaver (1986) findings. Our results on overall GT for all groups (8 hours/d) agree with those of Phillips and Leaver (1986) who suggested that the maximum GT for dairy cows in general is 6-9 h on a sward of 8-9 $\mathrm{cm}$ (measured by a rising plate meter). Although non-supplemented cows spent an additional 0.83 hours/d $(\mathrm{P}<.05)$ grazing, they grazed more efficiently, consuming $1.11 \mathrm{~kg}$ DM/hour compared to $\mathrm{H}$ level cows that consumed 0.62 $\mathrm{kg} \mathrm{DM} /$ hour. This indicates that the concentrate supplement could increase the energy expended by the animal to harvest a unit of forage. In addition, the lower digestibility of forage observed with high level of supplementation suggests that forage selectivity was not increased as forage DMI 
decreased, however, this conclusion is confounded by forage or concentrate associative effects.

Period influenced $(\mathrm{P}<.01)$ GT, in that cows spent an additional 1.2 hours/d grazing during P2 and P3 than in P1 (Table 9). The lack of a SH x supplement level x period or supplement level $\mathrm{x}$ period interaction $(\mathrm{P}>.10)$ on GT might suggest that the declining energy demands of the cows as milk production decreased may be the major factor influencing forage DMI as the season progressed. Forage DMI/hour of GT decreased $(\mathrm{P}<.01)$ as season progressed (Table 9) for several reasons such as declining pasture quality and herbage mass as well as energy needs of the cow.

\section{Live weight}

The sensitivity of weight change measurements was limited by the length of the experimental periods in this study. No SH x supplement level $x$ period interaction $(\mathrm{P}>.10)$ on average daily gain was evident. There was no interaction $(\mathrm{P}>.10)$ between $\mathrm{SH}$ and supplement level on average daily gain. Sward height had no effect ( $\mathrm{P}>.10)$ on daily gain of the cows or calves (Table 7). Supplemented cows gained more weight $(\mathrm{P}<.10)$ than non-supplemented cows (Table 8). Average daily gain of $\mathrm{H}$ calves was higher than $\mathrm{L}$ calves $(\mathrm{P}<.10)$ because $\mathrm{H}$ cows most likely partitioned more nutrients from concentrate supplement to support milk production. Period influenced average daily gain of cows $(\mathrm{P}<.04)$ and calves $(\mathrm{P}<.07)$. Cows made substantial daily gains during P1 $(2.6 \mathrm{~kg} / \mathrm{d})$, gained little weight during P2 (0.2 kg/d) and made modest gains during P3 (0.8 kg/d) (Table 9). The more rapid gain during P1 may be in part compensatory, because of increased diet quality as cows changed from winter ration of hay to pasture two weeks prior to the start of the study. The calves gained 1.4, 1.2 and $1.6 \mathrm{~kg} / \mathrm{d}$ during P1, P2 and P3, respectively. Calves gained more weight per day during P3 compared to other periods most likely because they were in that stage of the growth curve when their gain would be expected to be greater. 


\section{CHAPTER 5: SUMMARY AND CONCLUSION}

Expected three-way interactions between SH, supplement level and period or two-way interaction between SH and period were not realized. Cows on lower SH consumed more forage DM than those on higher SH. Forage DMI, digestibility and grazing efficiency decreased as the level of supplementation increased. Cows consumed more forage DM during P1 and P2 than they did in P3.

A lower SH resulted in higher forage DMI and quality forage, thus it can be suggested that cow/calves can be grazed at $\mathrm{SH}$ lower than $8 \mathrm{~cm}$ on cool season pastures similar to the one used in this study. Under most conditions, grazing at a lower SH would in general be more profitable because of increased stocking rate if animal performance is maintained. The decreased GT and efficiency of grazing activity by concentrate supplemented cattle may suggest that animal production/ha could also be enhanced by increasing the carrying capacity of pastures. High levels of concentrate supplementation decreased forage DMD and possibly increased energy expended for grazing activity. These factors may in part diminish the expected influence of increasing the energy density of the diet through supplementation on pasture to achieve an economically favorable production response.

Because of decreased grazing efficiency and negative associative effects on forage DMD, timing of grazing and supplementation with concentrates could possibly influence animal production efficiency. 


\section{$\underline{\text { Literature cited }}$}

Akin, D. E. 1989. Histological and physical factors affecting digestibility of forages. Agronomy J. 81: $17-25$.

Akin, D. E., R.H. Brown and L. L. Rigsby. 1984. Digestion of stem tissues in Panicum species. Crop Sci. 24: 769-773.

Akin, D. E. 1982. Microbial breakdown of feed in the digestive tract. In: Nutritional limits to Animal Production from Pastures (Ed. J. B. Hacker). Farnham Royal, U. K. Commonwealth Agricultural Bureaux, pp. 201-223.

Albrecht, K. A., W.F. Wedin and D. R. Buxton. 1987. Cell-wall composition and digestibility of Alfalfa stems and leaves. Crop Sci. 27: 735-741.

Allden, W.G., and I. A. McD. Whittaker. 1970. The determinations of herbage intake by grazing sheep: The interrelationships of factors influencing herbage intake and availability. Aust. J. Agric. Res., 21; 755-766.

AOAC. 1990. Official methods of Analysis (15 ${ }^{\text {th }}$ Ed.). Association of Official Analytical Chemists, Washington, DC.

Armstrong, D. G. 1982. Digestion and utilization of energy. In: Nutritional Limits to Animal Production from Pastures (Ed. J. B. Hacker). Farnham Royal, U. K., Commonwealth Agricultural Bureaux, pp. 225-244.

Arnold, G. W. 1962. Effects of pasture maturity on the diet of sheep. Austr. J. Agric. Res. 13: 701706.

Baker, R. D., Y. L. P. Le Du and F. Alvarez. 1981a. The effect of herbage allowance upon the herbage intake and performance of suckler cows and calves. Grass and Forage Sci. 36: 186199.

Baker, R. D., Y. L. P. Le Du and F. Alvarez. 1981b. The herbage intake and performance of setstocked suckler cows and calves. Grass and Forage Sci. 36: 201-210.

Baker, M. J., E. C. Prigge and W. B. Bryan. 1988. Herbage Production from Hay fields Grazed by Cattle in Fall and Spring. J. Prod. Agric. 31: 275-279.

Barnes, R. F., D. A. Miller, and C. J. Nelson. 1995. Forages. Vol. I: An introduction to Grassland Agriculture. Iowa State Univ. Press, Ames, Iowa, USA. pp. 105-115.

Barthram, G. T. 1986. Experimental techniques: the HFRO sward stick. Biennial Report, Hill Farming Research Organization. 1984-85, pp 29-30. 
Belesky, D. P and J. M. Fedders. 1994. Defoliation effects on seasonal production and growth rate of cool-season grasses. Agron. J. 86: 38-45.

Blaxter, K. L. and R. S. Wilson. 1963. The assessment of a crop husbandry technique in terms of animal production. Anim. Prod. 5: 27-42.

Bryan, W. B., W. V. Thayne and E. C. Prigge. 1990. Sward height and capacitance probe for estimating herbage mass. J. Agron. Crop Sc. 164: 208-212.

Bryan, W. B and T. A. Mills. 1988. Seasonality of pasture growth in West Virginia. Proc. $12^{\text {th }}$ Gen. Meeting European Grassland Fed., 4-7 July 1988, Dublin, Ireland. P. 382-386.

Butris, G. Y and C. J. C. Phillips. 1987. The effect of surface water and provision of supplementary forage on the intake and feeding behavior of cattle. Grass and Forage Sci. 42: 254-264.

Cazcarra, R. F., M. Petit and P. D'hour. 1995. The effect of sward height on grazing behavior and herbage intake of three sizes of Charolais cattle grazing Cocksfoot (Dactylis glomerata L.) swards. Anim. Sci. 61: 511-518.

Chacon, E. and T. H. Stobbs. 1976. Influence of progressive defoliation of a grass sward on the eating behavior of cattle. Aust. J. Agric. Res. 27: 709-727.

Conrad, H. R. 1966. Symposium on factors influencing the voluntary intake of herbage by ruminants: Physiological and physical factors limiting feed intake. J. Anim. Sci. 25: 227-235.

Demment, M. W and G. B. Greenwood. 1988. Forage ingestion: effects of sward characteristics and body size. J. Anim. Sci. 66 ; 2380-2392.

Dulphy, J. P., B. Remond and M. Theriez. 1980. Ingestive behavior and related activities in ruminants. In: Digestive physiology and metabolism in ruminants, ed. Y. Ruckenbusch and P. Thivend, pp. 103-122.

Elliot, R. C. and J. H. Topps. 1963. Voluntary intake of low protein diets by sheep. Anim. Prod. 5: $\quad 269-276$.

Forbes, J. M. 1995. Voluntary Food Intake and Diet selection in Farm Animals. CAB International, pp. 211-212.

Gibb, M. J., C. A. Huckle, R. Nuthall and A. J. Rook. 1997. Effect of sward surface height on intake and grazing behavior by lactating Holstein Friesian cows. Grass and Forage Sci. 52: 309-321.

Goering, H. K and P. J. Van Soest. 1970. Forage fiber analysis (apparatus, reagents, procedures and some applications). Agric. Handbook 379. ARS, USDA, Washington, DC. 
Grant, R. J., P. J. van Soest, R. W. McDowell and C. B. Perez Jr. 1976. Intake, digestibility and metabolic loss of napier grass by cattle and buffaloes when fed wilted, chopped and whole. J. Anim. Sci. 39: 423-434.

Greenhalgh, J. F. D., G. W. Reid, J. N. Aitken and E. Florence. 1966. The effect of grazing intensity on herbage consumption and animal production. I. Short-term effects in strip-grazed dairy cows. J. Agric. Sci. Camb. 67: 13-23.

Greenhalgh, J. F. D., G. W. Reid and J. N. Aitken. 1966. The effect of grazing intensity on herbage consumption and animal production. II. Longer-term effects in strip-grazed dairy cows. J. Agric. Sci. Camb. 69: 217-223.

Griffin, J. L and G. A. Jung. 1983. Leaf and stem forage quality of Big Bluestem and Switch grass. Agronomy J. 75: 723-726.

Harris, W. 1978. Defoliation as a determinant of the growth, persistence, and composition of pasture. p. 67-85. In: J. R. Wilson (ed), CSIRO. Plant Relations in pastures. Canberra, Australia.

Hegarty, M. P. 1982. Deleterious factors in forages affecting animal production. In: Nutritional Limits to Animal Production from Pastures (Ed. J. B. Hacker). Farnham Royal, U. K., Commonwealth Agricultural Bureaux, pp. 133-150.

Hall, J. L., T. J. Flowers and R. M. Roberts (Eds.). 1974. Plant cell structure and metabolism. Longman Group Ltd., London, pp. 338-372.

Hodgson, J. 1990. Grazing Management: science into practice. Longman group UK. Pp. 65-76.

Holmes, W., J. G. W. Jones and R. M. Drake-Brockman. 1962. The feed intake of grazing cattle. II. The influence of size of animal on feed intake. Anim. Prod. 3: 251-260.

Hoover, W. H. 1986. Chemical factors involved in ruminant fiber digestion. J. Dairy Sci. 69: 27552766.

Jameison, W. S and J. Hodgson. 1979. The effect of daily herbage allowance and sward characteristics upon the ingestive behavior and herbage intake of calves under strip-grazing management. Grass and Forage Sci. 34: 261-271.

Jameison, W. S and J. Hodgson. 1979. The effect of variation in sward characteristics upon ingestive behavior and herbage intake of calves and lambs under a continuous stocking management. Grass and Forage Sci. 34: 273-282.

Jennings, P. G. and W. Holmes. 1984. Supplementary feeding of dairy cows on continuously stocked pasture. J. Agric. Sci. Camb. 103: 161-170. 
Krysl, L. J. and B. W. Hess. 1993. Influence of supplementation on behavior of grazing cattle. J. Anim. Sci. 71: 2546-2555.

Leaver, J. D. 1982. Grass height as an indicator for supplementary feeding of continuously stocked dairy cows. Grass and Forage Sci. 37: 285-290.

Leaver, J. D. 1985. Milk production from grazed temperate grassland. J. Dairy Sci. 52: 313-344.

Leaver, J. D. 1986. Effect of supplements on herbage intake and performance. In: Grazing ;occasional symposium number 19 (Ed. J. Frame), British Grassland Society, pp. 79-88.

Le Du, Y. L. P and R. D. Newberry. 1982. Supplementing the grazing dairy cow during period of pasture restriction. Grass and Forage Sci. 37: 173-174.

Le Du, Y. L. P., R. D. Baker and R. D. Newberry. 1979. Supplementary feed in the diet of dairy cows offered fresh herbage. Anim. Prod. 28: 413.

Mayne, C. S., R. D. Newberry, S. C. F. Woodcock and R. J. Wilkins. 1987. Effect of grazing severity on grass utilization and milk production of rotationally grazed dairy cows. Grass and Forage Sci. 42: 59-72.

Meijs, J. A. C and J. A. Hoekstra. 1984. Concentrate supplementation of grazing dairy cows. I. Effect of concentrate intake and herbage allowance on herbage intake. Grass and Forage Sci. 39: 5966.

Minson, D. J. 1982. Effects of chemical and physical composition of herbage upon intake. In: Nutritional Limits to Animal Production from Pastures (Ed. J. B. Hacker). Farnham Royal, U. K. Commonwealth Agri. Bureaux, pp. 167-182.

Minson, D. J. 1990. Forage in Ruminant Nutrition. Academic Press Inc., San Diego, California, pp.17-44.

Mould, F. L and E. R. Orskov. 1984. Manipulation of rumen fluid $\mathrm{pH}$ and its influence on cellulolysis in sacco, dry matter degradation and the rumen microflora of sheep offered either hay or concentrate. Anim. Feed Sci. Technol. 10:1.

Muinga, R. W., W. Thorpe and J. H. Topps. 1992. Voluntary food intake, live-weight change and lactation performance of crossbred dairy cows given ad libitum Pennisetum purpureum (napier grass var. Bana) supplemented with leucaena forage in the lowland semi-humid tropics. Anim. Prod. 55: 331-337.

National Research Council. 1989. Nutrient Requirements of Dairy Cattle.

Pasha, T. N., E. C. Prigge, R. W. Russell and W. B. Bryan. 1994. Influence of moisture content of forage diets on intake and digestion by sheep. J. Anim. Sci. 72: 2455-2463. 
Pearson, C. J. and R. L. Ison (Eds.). 1997. Agronomy of Grassland Systems, $2^{\text {nd }}$ edition, Cambridge University Press, pp. 74-95.

Penning, P. D and G. E. Hooper. 1985 a. An evaluation of the use of short-term weight changes in grazing sheep for estimating herbage intake. Grass and Forage Sci. 40: 79-84.

Penning, P.D., A. J. Parsons, R. J. Orr and T. T. Treacher. 1991. Intake and behavior responses by sheep to changes in sward characteristics under continuous stocking. Grass and Forage Sci. 46: $15-28$.

Phillips, C. J. C. and J. D. Leaver. 1985. Supplementary feeding of forage to grazing dairy cows. I. Offering hay to dairy cows at high and low stocking rates. Grass and Forage Sci. 40: 183-192.

Phillips, C. J. C. and J. D. Leaver. 1985. Supplementary feeding of forage to grazing dairy cows. II. Offering grass silage in early and late season. Grass and Forage Sci. 40: 193-199.

Phillips, C. J. C. and J. D. Leaver. 1986. The effect of forage supplementation on the behavior of grazing dairy cows. Appl. Anim. Behavior Sci. 16: 233-247.

Prigge, E. C., W. B. Bryan and E. L. Nestor. 1997. Sward height on performance of cow-calf units and yearling steers grazing cool season pasture. Proceedings of the XVIII International Grassland Congress, Winnipeg/Saskatoon, Canada. 29: 97-98.

Rayburn, E. B and S. B. Rayburn. 1998. A standardized plate meter for estimating pasture mass in on-farm research trials. Agron. J. 90: 238-241.

Robertson, J. B and P. J. Van Soest. 1981. The detergent system of analysis and its application to human foods. In: W. P. T. James and O. Theander (Ed.). The analysis of Dietary Fiber. Pp 123-158. Marcell Dekker, New York.

Rook, A. J., C. A. Huckle and P. D. Penning. 1994. Effects of sward height and concentrate supplementation on ingestive behavior of spring-calving dairy cows grazing grass-clover swards. Appl. Anim. Behav. Sci. 40: 101-112.

Rook, A. J., C. A. Huckle and R. J. Wilkins. 1994. The effects of sward height and concentrate supplementation on the performance of spring calving dairy cows grazing perennial ryegrasswhite clover sward. Anim. Prod. 58: 167-172.

Sarker, A. B. and W. Holmes. 1974. The influence of supplementary feeding on the herbage intake and grazing behavior of dry cows. J. British Grassland Soc. 29: 141-143.

SAS Institute, Inc. 1985. SAS users' guide: statistics. Version 5 edition. SAS Institute, Inc., Cary, NC. 
Siebert, B. D. and R. A. Hunter. 1982. Supplementary feeding of grazing animals. In: Nutritional Limits to Animal Production from Pastures (Ed. J. B. Hacker). Farnham Royal, U. K., Commonwealth Agri. Bureaux, pp. 409-426.

Stobbs, T. H. 1973. The effect of plant structure on the intake of tropical pastures. I. Variation in the bite size of grazing cattle. Aust. J. Agric. Res. 24: 809-819.

Sunvold, G. D and R. C. Cochran. 1991. Evaluation of ADL, APL, AIA, and IADF as internal markers for prediction of Alfalfa, Bromegrass, and Prairie hay digestibility by beef steers. J. Anim. Sci. 69: 4951-4955.

Van Soest, P. J. 1994. Nutritional Ecology of the Ruminant. Cornell Univ. Press, Ithaca, New York, pp. 165-195.

Van Soest, P. J., J. B. Robertson and B. A. Lewis. 1991. Methods for Dietary Fiber, Neutral Detergent Fiber and Non-starch Polysaccharides in relation to Animal Nutrition. J. Dairy Si 74: 3583-3597.

Weston, R. H. 1982. Animal factors affecting feed intake. In: Nutritional Limits to Animal Production from Pastures (Ed. J. B. Hacker). Farnham Royal, U. K., Commonwealth Agri. Bureaux, pp. 183-198.

Wilson, J. R., R. H. Brown and W. R. Windham. 1983. Influence of leaf anatomy on the Dry Matter digestibility of $\mathrm{C}_{3}, \mathrm{C}_{4}$, and $\mathrm{C}_{3} / \mathrm{C}_{4}$ intermediate types of Panicum species. Crop Sci. 23: 141146.

Wright, I. A. and T. K. Whyte. 1989. Effects of sward surface height on the performance of continuously stocked spring-calving beef cows and their calves. Grass and Forage Sci. 44: $259-266$.

Wright, I. A., T. K. Whyte and K. Osoro. 1990. The herbage intake and performance of autumncalving beef cows and their calves when grazing continuously at two sward heights. Anim. Prod. 51: 85-92.

Zoby, J. L. F. and W. Holmes. 1983. The influence of size of animal and stocking rate on the herbage intake and grazing behavior of cattle. J. Agric. Sci. Camb. 100: 139-148. 


\section{TABLES}

\section{Table 1: Composition of Energy Supplement}

Ingredient

\%DM basis

Dent Yellow Corn, ground

82.6

Soy bean meal, solvent extracted,

$44 \%$ protein

16.4

Limestone, ground

1.0

$\underline{\text { Table 2: Nutritional Value of Concentrate Supplement }}$

Nutrient

Value (DM basis)

Net energy for maintenance, Mcal/kg

2.07

Net energy for gain, Mcal $/ \mathrm{kg}$

1.41

Net energy for lactation, Mcal/kg

1.94

Crude protein, $\%$

16.45

Calcium, \%

0.40

Phosphorus, \%

0.35

${ }^{a}$ Values based on Nutrient requirements of dairy cattle (NRC, 1989) 
Table 3: Effect of Sward Height on Botanical Composition of Pasture

Sward height

\begin{tabular}{|c|c|c|c|c|}
\hline$\underline{\text { Variable }}$ & $4-8 \mathrm{~cm}$ & $8-11 \mathrm{~cm}$ & SEM & Significance \\
\hline Mean $\mathrm{SH}^{1}, \mathrm{~cm}$ & 6.6 & 8.8 & & \\
\hline Mean $\mathrm{SSH}^{2}, \mathrm{~cm}$ & 7.2 & 9.8 & & \\
\hline Herbage mass, $\mathrm{kg}$ DM/ha & 1446.0 & 1955.0 & & \\
\hline $\begin{array}{l}\text { Herbage growth rate } \\
\mathrm{kg} / \mathrm{ha} / \mathrm{d}\end{array}$ & 45.1 & 36.4 & 5.4 & $\mathrm{NS}^{\mathrm{b}}$ \\
\hline Grass, $\%$ of DM & 55.3 & 50.9 & 1.7 & $*$ \\
\hline Legume, $\%$ of DM & 16.8 & 13.1 & 1.8 & NS \\
\hline Weeds, $\%$ of DM & 10.6 & 11.8 & 1.3 & NS \\
\hline Dead material, $\%$ of DM & 17.3 & 24.2 & 2.1 & $* *$ \\
\hline
\end{tabular}

${ }^{\mathrm{a}} \mathrm{Herbage}$ growth rate $=$ seasonal growth rate of pasture; ${ }^{\mathrm{b}} \mathrm{NS}=$ non significance; $* *=\mathrm{p}<0.05$;

$*=\mathrm{P}<.10$

${ }^{1} \mathrm{SH}=$ sward height estimated by a plate meter

${ }^{2} \mathrm{SSH}=$ estimated HFRO sward stick sward height 
Table 4: Effect of Period on Herbage Growth Rate and Botanical Composition of Pasture

\begin{tabular}{|c|c|c|c|c|c|}
\hline \multirow[b]{2}{*}{ Variable } & \multicolumn{3}{|c|}{ Period } & \multirow[b]{2}{*}{ SEM } & \multirow[b]{2}{*}{ Significance } \\
\hline & 1 & 2 & 3 & & \\
\hline Mean $\mathrm{SH}^{1}, \mathrm{~cm}$ & 8.4 & 7.5 & 7.2 & & \\
\hline Mean $\mathrm{SSH}^{2}, \mathrm{~cm}$ & 9.4 & 8.3 & 7.9 & & \\
\hline $\begin{array}{l}\text { Herbage growth rate, } \\
\mathrm{kg} / \mathrm{ha} / \mathrm{d}\end{array}$ & 56.2 & 35.7 & 30.4 & 6.6 & $* *$ \\
\hline Grass, $\%$ of DM & 53.5 & 46.6 & 59.1 & 2.1 & $* *$ \\
\hline Legume, $\%$ of DM & 14.2 & 18.9 & 11.8 & 2.2 & $N S^{\mathrm{a}}$ \\
\hline Weeds, \% of DM & 12.6 & 9.7 & 11.3 & 1.6 & NS \\
\hline $\begin{array}{l}\text { Dead material, } \\
\% \text { of DM }\end{array}$ & 19.7 & 24.8 & 17.8 & 2.5 & NS \\
\hline
\end{tabular}

${ }^{\mathrm{a}} \mathrm{NS}=$ non significance; $* *=\mathrm{P}<.05$

${ }^{1} \mathrm{SH}=$ sward height estimated by a plate meter

${ }^{2} \mathrm{SSH}=$ estimated HFRO sward stick sward height 
Table 5: Effect of Sward Height on Chemical Composition of Pasture

Sward height

\begin{tabular}{lcccc} 
Nutrient & $4-8 \mathrm{~cm}$ & $8-11 \mathrm{~cm}$ & SEM & Significance \\
\hline $\begin{array}{l}\text { Crude protein, \% of DM } \\
\text { Neutral detergent fiber, }\end{array}$ & 16.2 & 14.8 & 0.5 & $*$ \\
\% of DM & 58.5 & 61.0 & 0.8 & $*$ \\
$\begin{array}{l}\text { Acid detergent fiber, } \\
\text { \% of DM }\end{array}$ & 31.8 & 32.9 & 0.7 & $\mathrm{NS}^{\mathrm{a}}$ \\
\hline
\end{tabular}

${ }^{\mathrm{a}} \mathrm{NS}=$ non significance; $*=\mathrm{P}<.10$.

Table 6: Effect of Period on Chemical Composition of Pasture

Period

\begin{tabular}{|c|c|c|c|c|c|}
\hline Nutrient & 1 & 2 & 3 & SEM & Significance \\
\hline $\begin{array}{l}\text { Crude protein, } \\
\% \text { of DM }\end{array}$ & 16.0 & 14.7 & 15.8 & 0.7 & $\mathrm{NS}^{\mathrm{a}}$ \\
\hline $\begin{array}{l}\text { Neutral detergent fibe } \\
\% \text { of DM }\end{array}$ & 56.8 & 59.1 & 63.2 & 1.0 & $* *$ \\
\hline $\begin{array}{l}\text { Acid detergent fiber, } \\
\% \text { of DM }\end{array}$ & 30.4 & 32.1 & 34.5 & 0.6 & $* *$ \\
\hline
\end{tabular}

${ }^{\mathrm{a}} \mathrm{NS}=$ non significance; $* *=\mathrm{P}<.05$ 


\section{Table 7: Effect of Sward Height on Animal Performance}

Sward height

\begin{tabular}{lcccc} 
& \multicolumn{3}{c}{ Sward height } & \\
\cline { 2 - 3 } Variable & $4-8 \mathrm{~cm}$ & $8-11 \mathrm{~cm}$ & SEM & Significance \\
\hline Total DMI, kg/d & 10.8 & 10.2 & 0.2 & $*$ \\
Forage DMI, kg/d & 7.7 & 7.1 & 0.2 & $*$ \\
GT $^{\mathrm{a}}, \mathrm{hr} / \mathrm{d}$ & 9.4 & 8.2 & 0.2 & $* *$ \\
Forage DMI, kg/hr GT & 0.8 & 0.9 & 0.1 & $\mathrm{NS}^{\mathrm{b}}$ \\
Forage DMD, \% & 70.0 & 67.2 & 1.7 & $\mathrm{NS}$ \\
ADG & & & \\
ADG, kg/d (cows) & 1.1 & 1.3 & 0.1 & $\mathrm{NS}$ \\
\hline
\end{tabular}

${ }^{\mathrm{a}} \mathrm{GT}=$ grazing time $;{ }^{\mathrm{b}} \mathrm{NS}=$ non significance $;{ }^{\mathrm{c}} \mathrm{ADG}=$ average daily gain $; *=\mathrm{P}<.10 ; * *=$ $\mathrm{P}<.05$ 
Table 8: Effect of Concentrate Supplement on Animal Performance Supplement level

\begin{tabular}{|c|c|c|c|c|c|}
\hline \multirow[b]{2}{*}{ Variable } & \multicolumn{3}{|c|}{ Supplement level } & \multirow[b]{2}{*}{ SEM } & \multirow[b]{2}{*}{ Significant Contrasts } \\
\hline & $\mathrm{H}$ & $\mathrm{L}$ & $\mathrm{U}$ & & \\
\hline Total DMI, kg/d & 11.1 & 10.7 & 9.8 & 0.5 & $\mathrm{H}>\mathrm{U}^{*}$ \\
\hline Forage DMI, kg/d & 4.9 & 7.5 & 9.8 & 0.5 & $\mathrm{H}<\mathrm{L}<\mathrm{U}^{* *}$ \\
\hline $\mathrm{GT}^{\mathrm{a}}, \mathrm{hr} / \mathrm{d}$ & 8.3 & 9.0 & 9.1 & 0.2 & $\mathrm{H}<\mathrm{L}^{* *}$ \\
\hline Forage DMI, $\mathrm{kg} / \mathrm{hr}$ GT & Г 0.6 & 0.9 & 1.1 & 0.1 & $\mathrm{H}<\mathrm{L}<\mathrm{U}^{* *}$ \\
\hline Forage DMD, \% & 63.2 & 69.9 & 72.6 & 1.4 & $\mathrm{H}<\mathrm{L}<\mathrm{U}^{* *}$ \\
\hline Total dig. ${ }^{\mathrm{b}} \mathrm{DMI}, \mathrm{kg} / \mathrm{d}$ & 8.4 & 7.9 & 7.1 & 0.4 & \\
\hline $\mathrm{ADG}^{\mathrm{c}}, \mathrm{kg} / \mathrm{d}(\mathrm{cows})$ & 1.3 & 1.5 & 0.8 & 0.2 & $\mathrm{H} \& \mathrm{~L}>\mathrm{U}^{*}$ \\
\hline ADG, $\mathrm{kg} / \mathrm{d}$ (calves) & 1.6 & 1.3 & 1.3 & 0.1 & $\mathrm{H}>\mathrm{L}^{*}$ \\
\hline
\end{tabular}

${ }^{\mathrm{a}} \mathrm{GT}=$ grazing time; ${ }^{\mathrm{b}}$ dig. $=$ digestible; ${ }^{\mathrm{c}} \mathrm{ADG}=$ average daily gain; $*=\mathrm{P}<.10 ; * *=\mathrm{P}<.05$ 


\section{Table 9: Effect of Period on Animal Performance}

\begin{tabular}{|c|c|c|c|c|c|}
\hline \multirow[b]{2}{*}{ Variable } & \multicolumn{3}{|c|}{ Period } & \multirow[b]{2}{*}{ SEM } & \multirow[b]{2}{*}{ Significance } \\
\hline & 1 & 2 & 3 & & \\
\hline Total DMI, kg/d & 11.3 & 11.3 & 8.9 & 0.5 & $* *$ \\
\hline Forage DMI, kg/d & 8.1 & 8.2 & 5.8 & 0.5 & $* *$ \\
\hline $\mathrm{GT}^{\mathrm{a}}, \mathrm{hr} / \mathrm{d}$ & 9.0 & 9.0 & 9.3 & 0.2 & $* *$ \\
\hline Forage DMI, $\mathrm{kg} / \mathrm{hr}$ G & $\Gamma 1.0$ & 0.9 & 0.7 & 0.1 & $* *$ \\
\hline Forage DMD, \% & 66.5 & 70.7 & 68.5 & 1.4 & $N S^{b}$ \\
\hline $\mathrm{ADG}^{\mathrm{c}}, \mathrm{kg} / \mathrm{d}$ (cows) & 2.6 & 0.2 & 0.8 & 0.7 & $* *$ \\
\hline ADG, kg/d (calves) & 1.4 & 1.2 & 1.6 & 0.1 & $*$ \\
\hline
\end{tabular}

${ }^{\mathrm{a}} \mathrm{GT}=$ grazing time $;{ }^{\mathrm{b}} \mathrm{NS}=$ non significance $;{ }^{\mathrm{c}} \mathrm{ADG}=$ average daily gain $; * *=\mathrm{P}<.05 ; *=$ $\mathrm{P}<.10$ 
Table 10: Mean Weekly Maximum and Minimum Temperature and Precipitation

\begin{tabular}{|c|c|c|c|}
\hline Week $^{\mathrm{a}}$ & $\operatorname{Maximum}\left({ }^{0} \mathrm{C}\right)$ & Minimum $\left({ }^{0} \mathrm{C}\right)$ & Precipitation $\left(\mathrm{mm}^{\mathrm{b}}\right)$ \\
\hline $5 / 07-5 / 13$ & 19.7 & 7.2 & 33.0 \\
\hline $5 / 14-5 / 20^{c}$ & 24.8 & 13.9 & 39.1 \\
\hline $5 / 21-5 / 27$ & 23.4 & 13.3 & 10.2 \\
\hline $5 / 28-6 / 03$ & 22.6 & 10.7 & 33.0 \\
\hline $6 / 04-6 / 10$ & 25.7 & 16.2 & 21.1 \\
\hline $6 / 11-6 / 17$ & 28.1 & 16.8 & 23.4 \\
\hline $6 / 18-6 / 24$ & 29.3 & 19.2 & 28.2 \\
\hline $6 / 25-7 / 01$ & 28.1 & 17.1 & 17.3 \\
\hline $7 / 02-7 / 08$ & 27.3 & 13.9 & 30.7 \\
\hline $7 / 09-7 / 15$ & 27.8 & 17.2 & 17.3 \\
\hline $7 / 16-7 / 22$ & 25.8 & 17.7 & 167.1 \\
\hline $7 / 23-7 / 29$ & 26.8 & 16.6 & 25.4 \\
\hline $7 / 30-8 / 05$ & 27.0 & 16.4 & 38.9 \\
\hline $8 / 06-8 / 12$ & 27.2 & 17.4 & 16.3 \\
\hline $8 / 13-8 / 19$ & 26.8 & 15.6 & 20.3 \\
\hline
\end{tabular}

${ }^{\mathrm{a}} \mathrm{Week}=$ weeks correspond to dates of $1996 ;{ }^{\mathrm{b}} \mathrm{mm}=$ millimeters $;{ }^{\mathrm{c}} 5 / 14-5 / 28=\mathrm{P} 1,6 / 25-7 / 09=\mathrm{P} 2$, and $8 / 06-8 / 20=\mathrm{P} 3$ 


\section{VITA}

Name: $\quad$ Ondieki J. Gekara

Date of Birth: $\quad$ July 19, 1961

Parents: $\quad$ James Gekara

Rebecca Gekara

Wife: $\quad$ Gladys Ondieki

Children: $\quad$ Acline, Albert and Annette Ondieki

Institutions Attended: $\quad$ Gesiaga Primary School, Kisii - Kenya $1968-1975$

Gesiaga Secondary School, Kisii - Kenya $\quad 1976$ - 1977

Sameta High School, Kisii - Kenya $\quad 1978$ - 1979

AHITI, Nyahururu - Kenya 1981 - 1983

Barneveld College, Netherlands $\quad 1987-1988$

West Virginia University, Morgantown WV 1994 - 1996

West Virginia University, Morgantown WV 1996 - 1999

Degrees Awarded: $\quad$ Certificate in Animal Health, AHITI -Nyahururu 1983

Diploma in Poultry Husbandry and Feed Milling

Technology, Barneveld College 1988

BS Agric (Animal and Vet Sciences) 1996

Employment: $\quad$ Ministry of Agriculture, Livestock Development and Marketing, Kenya

Title: $\quad$ Technical Officer 